\title{
THE RELATIONSHIP BETWEEN READING SKILLS AND METALINGUISTIC AWARENESS
}

\author{
Szilvia Varga * \\ Language Teaching and Examination Centre, John von Neumann University, Hungary \\ https://doi.org/10.47833/2021.1.ART.001
}

\section{Keywords:}

Reading skills

Metacognition

Metalinguistic awareness

Article history:

Received 13 Oct 2020

Revised 2 Apr 2021

Accepted 8 Apr 2021

\begin{abstract}
The objective of this study is to review approaches, hypotheses modeling reading comprehension in the first and second/ foreign languages. Mastering reading comprehension in foreign languages requires complex skills. Learners' experiences in reading in their first language can either support the development of their reading skills in the second or foreign language or they can become a source of interference. The contribution of the first language reading abilities to the second language reading skills highly depends on the similarities or the differences between the two languages and the learners' language competence in the second language. Fostering metalinguistic awareness is proposed to improve reading skills regardless of the differences between languages. Metalinguistic awareness is children's skill to objectify the language and pay attention to how the language works. Tasks related to the meaning and structure of the words, sentence parsing develop children's thinking skills and by this they can develop into better readers in both languages.
\end{abstract}

\section{Introduction}

Development of reading skills has always been important because the ability to read opens opportunities for people to learn more about the world. Research studies show that there is a link between good reading skills and overall attainment [8]. Thus reading acquisition in the first and second or foreign languages has become increasingly important. Good readers can become successful in different walks of life. Good readers are able to build a better vocabulary, acquire new knowledge and their language skills develop as well. Reading improves memory and language skills. However, weak readers try to avoid reading and they do not develop into better readers. They obtain grades below the average in all subjects. Under a certain level weak reading skills deprive people of making progress at school. As a result, weak reading skills threaten people's educational achievements [3].

The growing demand for workforce with developed literacy skills influence education systems which should prepare young people to meet the criteria of the labour market and future employers. The effectiveness of school education is measured by different tests, which assess the extent to which students acquired key knowledge and skills, which are essential for full participation in modern societies. The international surveys show that Hungarian students must improve their reading skills. Consequently, education must find the ways to facilitate enhancing literacy skill [8]. Acquisition of reading skills in the mother tongue lays the foundation for developing reading skills in foreign language skills. Even in the case of advanced level learners of English it is very difficult to

\footnotetext{
* Szilvia Varga

E-mail address:varga.szilvia@gamf.uni-neumann.hu
} 
exclude the mother tongue interference, especially when there is a difficult and complex concept is to be discussed and a precise definition is crucial [4] [6] [13] [17] [21].

\section{The linguistic background of reading comprehension}

The development of reading theories has led the researchers to the finding that word identification is a key factor in comprehension. Although brain research has revealed some important facts about cognitive processes which take place during the semantic processing of printed text, there are still debates about how exactly the reading process takes place and what are the most important factors that contribute to reading [19]. It is generally accepted that comprehension consists of two parts: decoding and comprehension. Decoding means turning the visual signals (graphemes) into phonemes. Comprehension means understanding the written words. Comprehension is linked to word recognition, vocabulary and language skills. Figure 1 shows the complex system which describes how the different linguistic elements take part in both decoding and comprehension. The reading system network is the basis of word identification models for the development of reading skills and reading difficulties [19]. Mental lexicon has primary importance since it links the word identification and the comprehension system. Figure 1 shows that morphology and syntax play an important role both as part of the linguistic system and it supports processing semantic information. The model represents all important factors of comprehension. The figure demonstrates the different processes of comprehension: decoding, word identification, retrieval of meaning, building of components, inferencing and utilizing different sources of knowledge in different ways. The Reading System Framework also shows the processes which take place in the Mental Lexicon and indicates the interaction among the different levels [19].

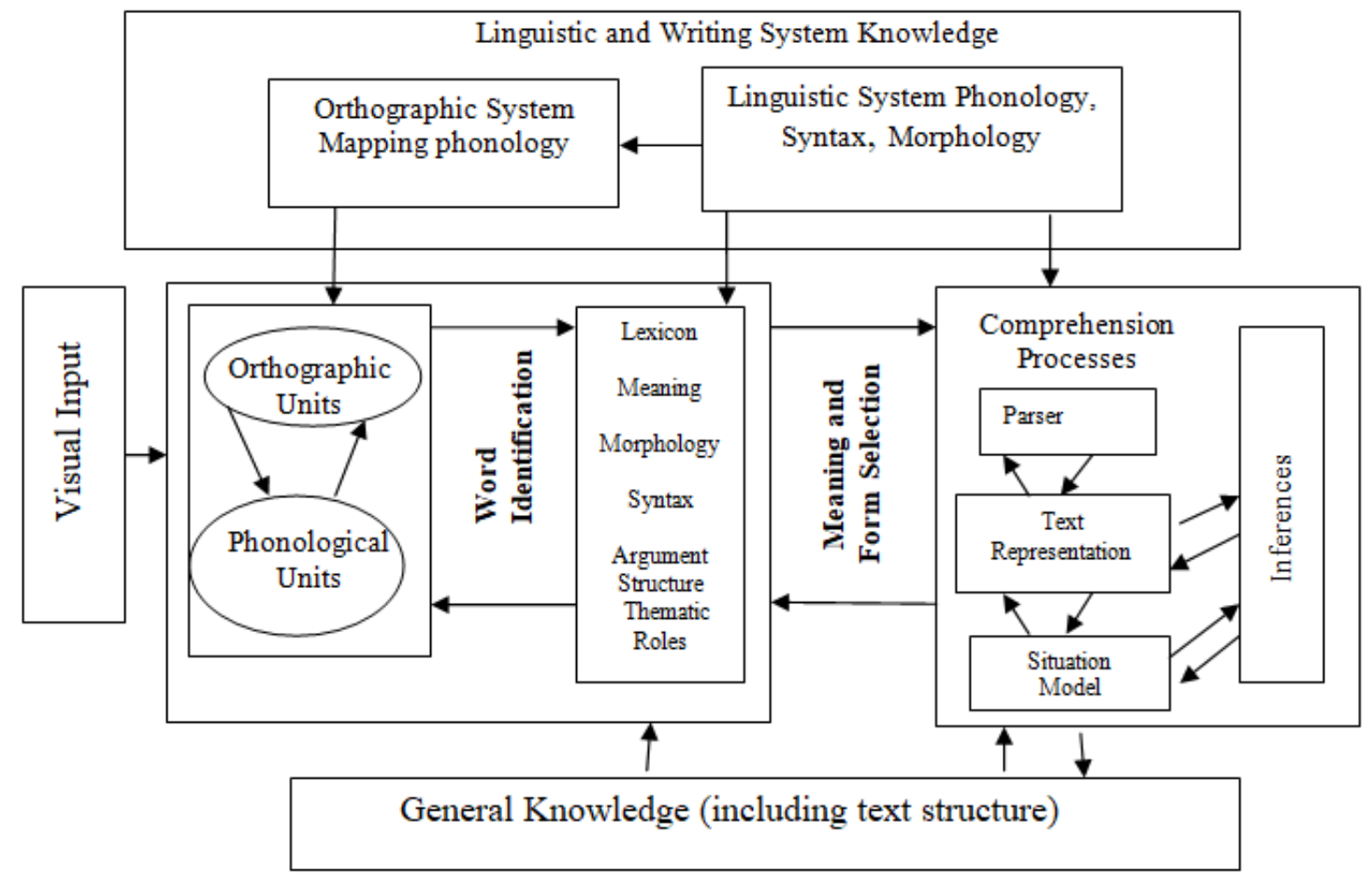

Figure1. Reading system framework [19]

Reading works similarly in all alphabetic languages [19]. Therefore, educational research carried out in bilinguals might help understand how reading skills in the first and second or foreign languages relate to each other. Bilingualism is a phenomenon when a person can speak more than one 
language. There are different hypotheses about how first language reading skills influence the second language reading skills. The Linguistic Threshold Hypothesis argues that students must have a sufficient amount of second language competence to make effective use of skills and strategies of their mother tongue reading comprehension abilities. This hypothesis claims that good $L 1$ reading skills cannot be automatically transferred into L2 reading skills. The second language knowledge (vocabulary, morphology syntax) is of primary importance in the process of becoming a good reader in the second or foreign language. However, advanced L2 learners can utilize their good first language reading skills when reading in the second language. For advanced second language learners the relationship between $\mathrm{L} 1$ and $\mathrm{L} 2$ reading skills becomes bidirectional which means that reading skills in one language support the development of reading skills in the other language. The developmental independence hypothesis suggests that reading experiences gained with the first language reading can promote the development controlling both languages [10] [21].

Another aspect of examining the process of reading in different languages is connected to word recognition which is linked to the basic reading skills. It is an interesting question that besides advanced L2 language skills what other factors support developing reading skills in L2. Studies regarding the reading skills of bilingual children found that the presentation of a word in one language activates orthographic, phonological, and semantic representations of all known languages. Bilinguals recognise the cognate words more quickly than monolinguals. Cognates are words that have the same origin as another word, or are related in some way to another word. Van Assche et al. investigated whether knowledge of a second language may still influence lexical access in a nativelanguage sentence context. They presented the exact same cognates and controls in a nativelanguage sentence context, and monitored participants' eye movements. The representations of a nondominant language, which was not relevant for text comprehension, were activated strongly enough to affect word recognition in the native tongue. When bilingual people read in their native language the second language is also activated in their brain. It was also supposed that the similarity of the languages might influence the extent the reading skills in the first language can facilitate developing reading skills in the second or foreign language [24]. It means that it is easier to learn a second or a foreign language when the first and the second languages are more similar to each other.

\section{Metacognition and reading skills}

Cognitive skills are crucial factors in reading skills. Linguistic processing has of primary importance especially in reading acquisition; however, reading is also perceived as information processing. Development of cognitive skills supports reading development in the first and in the second languages as well. The preconditions of early reading development include cognitive skills as working memory and phonological awareness. Phonological awareness belongs to metalinguistic skills. Figure 2 shows the structure of metacognitive skills and the system of metalinguistic skills. Metacognition encompasses awareness and understanding of one's own thought processes [12]. Metacognitive skills include different dimensions which gradually develop throughout school years. These dimensions consist of the individual's knowledge regarding memory, learning, linguistics, attention and social cognition skills [11] [14] [15]. Metacognitive research has made a great impact on literacy instruction in the last few decades. It is proposed that metalinguistic awareness underpins the development of reading skills. Especially, skilled readers can make use of metacognitive strategies to monitor their comprehension. Figure 2 describes the relationships between metacognition and metalinguistics. Metalinguistic awareness is comprised of phonological, semantic, syntactic and pragmatic awareness [16]. As it was mentioned phonological awareness is important at the onset of reading acquisition, it is the skill to reflect on, to identify and manipulate phonemes, semantic awareness is linked to recognising the meaning of words, syntactic awareness is a skill to understand the relationships among the words in the sentence, pragmatic awareness is explicit knowledge about pragmatics.

Metacognitive strategies are designed to monitor and control one's own cognitive activities, for example, reading and ensure that a cognitive goal is reached. [20]. Metacognitive experiences are also important in reading development in the first and second languages. They are connected to 
self-efficacy. Success, failure, frustration or satisfaction may determine interest or willingness to pursue similar tasks in the future. [18].

Metalinguistic knowledge means that the reader knows the structure of the language, how the texts are developed. Metalinguistic awareness is the ability to analyse, to talk and think about language as an object, independent of the concrete meaning of each word. Metalinguistic skills allow people to observe and control their use of language. Metalinguistic awareness is a type of metacognition, it is the skill to regard language as a code and distinguish it from its symbolic meaning. This cognitive skill also helps to understand language and its structure. Metalinguistic awareness skills can be a strong predictor of language development and ability to learn new languages. [16]

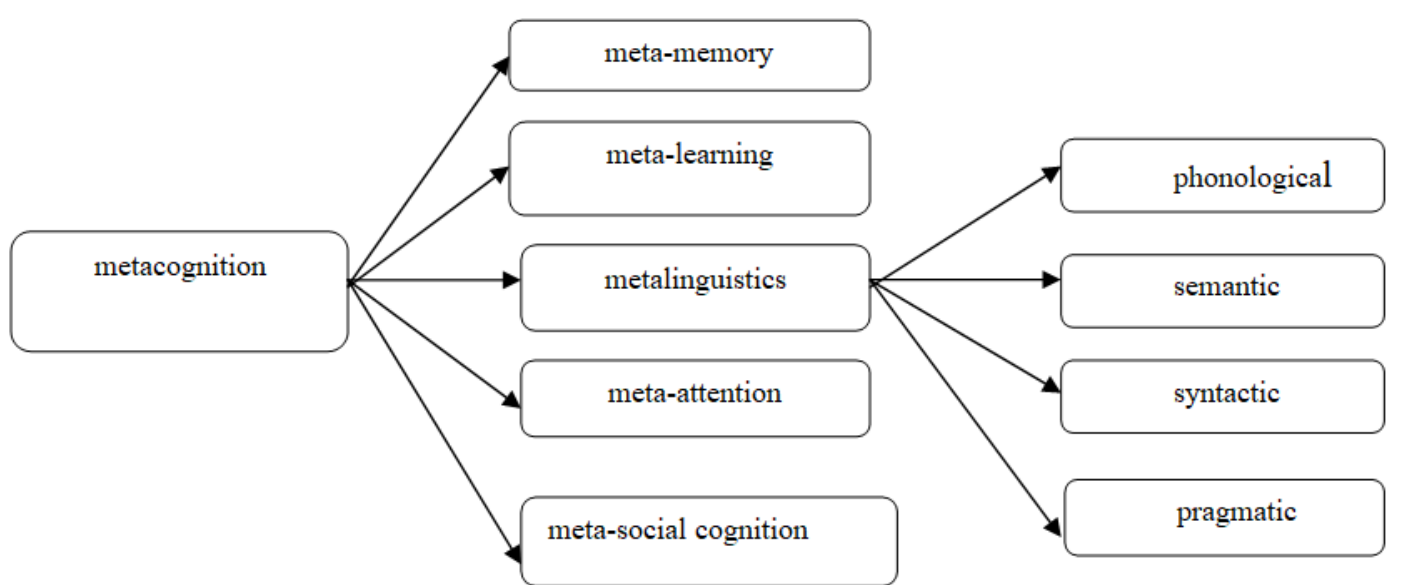

Figure 2 Relationships between metacognition and metalinguistics [20] [22]

There are three views on the nature of metalinguistic awareness. According to the first view, metalinguistic awareness appears at the beginning of the language acquisition process. The second one argues that it emerges when formal schooling begins, and the third one supposes that it develops after the child is introduced to formal schooling. In psychology, awareness is always connected with perception or knowledge of something. Accurate reportability of something perceived or known is widely used as a behavioural index of conscious awareness. However, it is possible to be aware of something without being explicitly conscious of it [16]. Metalinguistic awareness is important in learning to read, spell and understand words. It explains a portion of the otherwise unexplained variance in comprehension scores, when other important variables have been controlled. [16].

Decoding problems are associated with phonological awareness. Phonological awareness refers to the understanding of and access to the sound structure of spoken language, that is, the consciousness that oral language can be broken down into individual words, and words into phonemes. Csépe (2006) points out that phonological awareness is the ability to break the inner structure of the word into small parts analyze and manipulate the phonemes [9]. A main theoretical framework has been recently proposed which assumes that during reading acquisition, students learn to find shared grain sizes in orthography and in phonology [26].

Morphological awareness is also considered to be a metalinguistic skill. Morphological awareness is linked to semantic awareness. If students increase their knowledge of morphological awareness, they become aware that words which share the same root are similar in form and meaning. Morphological awareness also includes knowledge of common suffixes and prefixes [5]. Morphological awareness belongs to the cognitive processes; and as a child grows in morphological awareness, this can contribute to the child's cognitive development in general. From this point of view, it is obvious that morphological awareness supports both the development of literacy and cognitive skills, and it could also have an impact on reading comprehension skills [5] [25]. Syntactic awareness is referred to as the awareness of how sentences and texts are constructed, and the ability to understand how the language works on a sentence level. Pragmatic 
awareness involves knowledge of the rules underlying appropriate language use in particular communicative situations [1].

Children experience metalinguistic difficulties during reading activities. Recognising syllables, words, phrases and sentence boundaries can be challenging. The application of metacognitive reading strategies (making inferences, predictions) can also pose a challenge. Metacognitive reading strategies include making inferences and predictions related to the text. Metalinguistic needs include highlighting schema and explaining them to foster comprehension. Highlighting word boundaries and practising playing with word components are also beneficial. Children should practise segmenting words into morphemes [7].Ways to promote metalinguistic awareness consist of teaching multiple meanings of words (homonyms) [27]. Retelling stories, identifying morphemes, teaching figurative language and humour contribute to the development of academic performance. Metacogniton involves a higher level of cognitive process; therefore, teachers will be more aware of their students' cognitive and basic skill development. Metacogniton literacy instruction might help lifelong learners and writers who enjoy reading and writing and use literacy to improve and make their society better [21]. Applying metacognitive strategies to teaching reading is beneficial since metacogniton helps find the correct method to solve an individual task [20].

\section{Conclusions}

The aim of this paper was to discuss various models, approaches and hypotheses on reading comprehension in the first and second or foreign languages. Reading seems to show a number of similarities in all alphabetic languages. The comprehensive model of reading comprehension includes all the components of comprehension in which word recognition plays the most important part [19]. The contribution of the first language reading skills to the second language reading skills depends on multiple factors The learners' experiences in their first language can either facilitate the development of their reading skills in the second or foreign language or they can cause interference.. The similarities or the differences between the languages are important, and having sufficient language knowledge in the second/foreign language can influence the transfer as well. [13]. Besides linguistic processing, cognitive skills are also crucial in the development of the first and second language reading skills. Metalinguistic awareness is proposed to facilitate developing reading skills in different languages irrespectively of their orthographic and linguistic systems. Metalinguistic instruction can enhance the positive transfer between the mother tongue and foreign language reading skills [16]. In addition, tasks related to the meanings, structure of the words, sentences and texts foster children's thinking skills and by this they can develop into better readers in both languages.

\section{Acknowledgment}

This research is supported by EFOP-3.6.1-16-2016-00006 "The development and enhancement of the research potential at John von Neumann University" project. The Project is supported by the Hungarian Government and co-financed by the European Social Fund.

\section{References}

[1] Alcón, E. \& Safont, M. P.: Pragmatic awareness in second language acquisition. In J. Cenoz \& N. Hornberger (Eds.), Encyclopedia of language and education, 2008, Vol. 6, pp. 193-204. Berlin Springer.

[2] Alderson J. C.: Assessing Reading, 2000, Cambridge University Press. https://doi.org/10.1017/CBO9780511732935

[3] Arnbak, E.: When are poor reading skills a threat to educational achievement? 2004 Reading and Writing, 2004,17, 459-482 . https://doi.org/10.1023/B:READ.0000044595.76174.cC

[4] Bernard, E. B.: Progress and procrastinations in second language reading. Annual Review of applied linguistics, 2005, 25, 133-150. https://doi.org/10.1017/S0267190505000073

[5] Berninger, V. W., Abbott, R. D., Nagy, W. \& Carlisle, J.: Growth in phonological, orthographic, and morphological 
awareness in grades 1 to 6 . Journal of Psycholinguistic Research, 2010, 39, 141-63.

https://doi.org/10.1007/s10936-009-9130-6

[6] Brisbois, J. E.: Connections between First and Second Language Reading, Journal of reading Behaviour , (1995), Volume 27, number 4.https://doi.org/10.1080/10862969509547899

[7] Carlisle, J.F.: Effects of Instruction in Morphological Awareness on Literacy Achievement: An Integrative Review, Reading Research Quarterly, 2010, 45: 464-487. https://doi.org/10.1598/RRQ.45.4.5

[8] Csapó B.: A magyar közoktatás problémái az adatok tükrében. [Problems of the Hungarian Public Education based on data.] Iskolakultúra, 2015, 25 (7-8), 4-17. https://doi.org/10.17543/ISKKULT.2015.7-8.4

[9] Csépe, V.:Az olvasás rendszere, fejlődése és modelljei [The system of reading, reading acquisition and reading models] in Pléh, Cs. Eds. Psichoholinguisztika1-2. Magyar pszicholinguisztikai kézikönyv ,2014, pp. 339-370, Budapest, Akadémiai Kiadó.

[10] Cummins, J.: Linguistic interdependence and the educational development of Bilingual Children, Bilingual Education Paper Series, 1979, Vol. 3 No. 2. Los Angeles. p.1.

https://doi.org/10.3102/00346543049002222

[11] Flavell, J.H.: Metacognition and cognitive monitoring: a new area of cognitive-developmental inquiry. American Psychologist, 34, 1979, p. 906-911.

https://doi.org/10.1037/0003-066X.34.10.906

[12] Gombert, J.E.: Metalinguistic Development, 1992, University of Chicago Press, Chicago.

[13] Grabe, W. \& Stoller F. L.: Comparing L1 and L2 reading in Teaching and Researching Reading, 2011, pp 34-55., Great Britain, Pearson Education Limited, 2011.

[14] Hacker, D. J.: Definition and Empirical Foundations in Metacognition in Educational Theory and Practice Edited by Hacker D. J et al., 1998, pp. 1-25, Routledge, New York.

https://doi.org/10.4324/9781410602350

[15] Kopcikova, M. : Metacognition as a superordinate concept of metalinguistics: The role in developing reading skills in a foreign language. Crossroads, 3rd August, 2019.pp. 82-97 https://doi.org/10.15290/cr.2019.24.1.06

[16] Kuo, L. J., \& Anderson, R. C.: Morphological awareness and learning to read: A cross language perspective.

Educational Psychologist, 2006, 41(3), 161-180. https://doi.org/10.1207/s15326985ep4103 3

[17] McNeil, L.: Extending the compensatory model of second language reading. System, 2012, 40(1), 64-

76.https://doi.org/10.1016/j.system.2012.01.011

[18] Papaleontiou-Louca, E.: Metacognition and Theory of Mind, 2008, pp.27-31.Cambridge Scholars Publishing.

[19] Perfetti, C. \& Stafura, J. : Word Knowledge in a Theory of Reading Comprehension, Scientific Studies of Reading, 2014, 18:1, 22-37. https://doi.org/10.1080/10888438.2013.827687

[20] Sinar, B.: Promoting metalinguistic awareness in a classroom to improve reading comprehension: Examples from Roald Dahl's novel The BFG. Acta Didactica Norge, 2018, 12(2), Art. 11, 22 sider. https://doi.org/10.5617/adno.5605

[21] Tánczikné Varga, Sz.: Reading models in L1 and L2, (2017), Gradus 4: 1 pp. 144-156.

[22] Tunmer, W. E. \& Bowey, J.: Metalinguistic Awareness and Reading Acquisition. In W. E. Tunmer, C. Pratt, \& M. L. Herriman (Eds.), Metalinguistic Awareness in Children: Theory, Research and Implications, 1984, (pp. 144-168). Berlin: Springer-Verlag. https://doi.org/10.1007/978-3-642-69113-3 9

[23] Urquhart, A. \& Weir, C.: Reading in a Second Language: Process, Product and Practice, 1998, pp.1-7; 37-51, London: Longman.

[24] Van Assche, E., Duyck, W., Hartsuiker, R. J, and Diependaele K.: Does Bilingualism Change Native-Language Reading? Cognate Effects in a Sentence Context, Psychological Science, 2009, 20(8):923-7. https://doi.org/10.1111/j.1467-9280.2009.02389.x

[25] Varga, Sz., Pásztor, A. \& Steklács, J.: An online instrument assessing the relationship between morphological structure awareness and reading comprehension in Hungarian 2-4 graders. Ilkogretim Online - Elementary Education Online, 2020, 19 (4): pp. 2322-2334. https://doi.org/10.17051/ilkonline.2020.764232

[26] Ziegler, J. \& Goswami, U.: Reading Acquisition, Developmental Dyslexia, and Skilled Reading Across Languages: A Psycholinguistic Grain Size Theory, Psychological Bulletin Copyright 2005 by the American Psychological Association, 2005, Vol. 131, No. 1, 3-290033-2909/05/\$12.00 DOI: 10.1037/0033-2909.131.1. https://doi.org/10.1037/0033$\underline{2909.131 .1 .3}$

[27] Zipke, M., Ehri, L. E., \& Cairns, H.: Using semantic ambiguity instruction to improve third graders' metalinguistic awareness and reading comprehension: An experimental study. Reading Research Quarterly, 2009, 44(3), $300-321$. https://doi.org/10.1598/RRQ.44.3.4 